ROCZNIKI TEOLOGICZNE

Volume 65, issue $7-2018$

Englis h version

DOI: http://dx.doi.org/10.18290/rt.2018.65.7-2en

\title{
KRZYSZTOF LEŚNIEWSKI
}

\section{MAN AS A PERSON IN THE MYSTICAL ANTHROPOLOGY OF VLADIMIR LOSSKY}

\begin{abstract}
A b s tract. The notion "person" has been of great importance in European civilization for several centuries. The formation of its content range was conditioned by the philosophical, theological, and cultural influences of Europe's two major civilization centres, namely the Byzantine Empire and the Roman Empire. The important question therefore becomes: What are the differences in the understanding of the concept of "person" between the world of the Christian East and the world of the Christian West. In search of an answer to this question, the article is a reflection on the views of an outstanding Orthodox theologian-Vladimir Lossky. For decades, his theological heritage has been inspiring both Orthodox and Catholic theologians, constituting an important point of reference in the interpretation of the Church Fathers.
\end{abstract}

Key words: person; man; theological anthropology; Vladimir Lossky.

The concept of "person" is a great contribution of Christianity not only to European civilization but also to global civilization. ${ }^{1}$ It is of revolutionary significance, because it contributed to great changes in the way of perceiving man both in the Byzantine Empire and in the Roman Empire. ${ }^{2}$ In these two

Prof. KRZYSZTOF LeŚNIEWSKI, PHD, DSC - Head of the Department of Orthodox Theology at the Ecumenical Institute of the John Paul II Catholic University of Lublin; address for correspondence — e-mail address: lesni@ @ul.pl

${ }^{1}$ Cf. Hans Urs von Balthasar, "On the Concept of Person," Communio 13 (1986): 18-26; Oliver ClÉMENT, Questions sur l'homme (Paris: Stock, 1972), passim; Juan Manuel BuRGos, Personalizm. Autorzy i tematy nowej filozofii, trans. Krzysztof Koprowski (Warsaw: Centrum Myśli Jana Pawła II, 2010), passim; John F. Crosby, The Selfhood of the Human Person (Washington, D.C.: The Catholic University of America Press, 1996), passim; Wincenty Granat, Osoba ludzka. Próba definicji (Sandomierz: Wydawnictwo Diecezjalne, 1961), passim; Paul TouRNIER, Le personnage et la personne (Neuchâtel: Delachaux et Niestlé, 1954), passim.

${ }^{2}$ Cf. Adam RodziŃSkI, Osoba i kultura (Warsaw: Ośrodek Dokumentacji i Studiów Społecznych, 1985); Cornelia Johanna de Vogel, "The Concept of Personality in Greek and Christian Thought," in Studies in Philosophy and the History of Philosophy, vol. 2, ed. John K. Ryan (Washington, D.C.: Catholic University of America Press, 1963), 20-60; Steven LuKES, Michael 
political, social, and cultural realms, the understanding of man was determined by various kinds of factors, resulting in certain perceptible differences in the way of treating this philosophico-religious category between Eastern and Western Christendom. ${ }^{3}$ How did the concept of person develop? Why did Christians in the early centuries make the effort of creating a category that could express the truth about the mystery of God and the mystery of man? What are the differences in the understanding of the concept of "person" between the Christian West and the Christian East? How similar or how different are the paths taken in defining person in these two major traditions of Christianity? In search of answers to these questions, it is worth analysing Vladimir Lossky's works, which, for several decades, have inspired many theologians, both Orthodox and Catholic, to engage in anthropological and Trinitarian reflection.

\section{EASTERN CHRISTIAN UNDERSTANDING OF THE PERSON}

The concept of person, so obvious in the contemporary world, was incomprehensible in antiquity, both in Europe and in other parts of the world. Vladimir Lossky rightly points out that in the ancient world people were treated as human individuals. ${ }^{4}$ Interesting reflections on the role and understanding of man in ancient Greek civilization can be found in Being as Communion, a publication by Metropolitan John Zizioulas, who drew on Lossky's Mystical Theology of the Eastern Church. It is widely known that ancient Greek thought was basically "non-personal." In Platonic philosophy, everything that is concrete and individual ultimately relates to an abstract idea as its basis and final justification. This assumption makes the concept of person ontologically impossible because the soul that ensures the continuity of a human individual's existence is not permanently and inseparably linked to a particular individual's body. The soul lives eternally

CArrithers, and Steven Collins, eds., The Category of Person: Anthropology, Philosophy, History (Cambridge: Cambridge University Press, 1987), passim.

${ }^{3}$ Cf. Hans G. KipPEnBerg, Yme B. KuIPER, and Andy F. SANDERs, eds., Concepts of Person in Religion and Thought (Berlin-New York, NY: De Gruyter, 1990), passim; Joseph RATZINGER, "Concerning the Notion of Person in Theology," Communio 17 (1990): 439-454.

${ }^{4}$ Vladimir Lossky, Teologia mistyczna Kościoła Wschodniego, trans. Maria M. Sczaniecka (Warszawa: PAX, 1989), 47.

${ }^{5}$ John D. Zizioulas, Being as Communion. Studies in Personhood and the Church (London: Longman and Todd, 1985), 27. 
and may unite with one human body or another, thus making up a specific individual through reincarnation. ${ }^{6}$ This means a human being does not exist as an inseparable combination of a specific soul with a particular body that make up an individual human being in a permanent way. For Aristotle, the concept of person is not possible either, since the soul is linked to a specific individual - a human being. This psychosomatic unity exists until the moment of death. What occurs as a result of death is the complete and final "decomposition" of this particular "individual." Therefore, according to the Stagirite, a specific individual cannot be eternal. Death puts an end to the

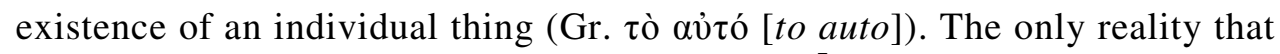

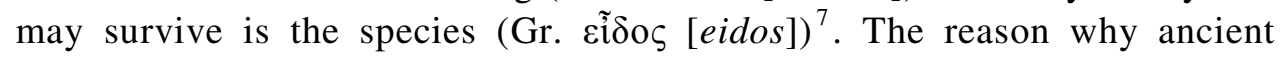
Greek philosophy was unable to confer permanent individuality is deeply rooted in Greek thinking, which was marked by ontological monism. Mistrust of distinction or contingency was caused by a fear that this kind of tendency would lead to the collapse of being and to nonexistence. As an alternative, ancient Greeks adopted the concept of cosmos, which was treated as a harmonious community of the existing realities - a world full of internal dynamism and aesthetic fullness, a beautiful and divine world. ${ }^{8}$ People desire to preserve their own identity and try to exist excluding one another. Everyone affirms himself or herself by comparing oneself with others, which, in practice, consists in striving to distinguish oneself from others and to divide the unity of human nature in such a way as to have some part of it for oneself. Thus understood, man is not truly a person but an individualthat is, part of the nature shared with others. ${ }^{9}$

It is true that if the concept of hypostasis is purified of Aristotelian contents, man will be understood as a person, in the contemporary sense of the word, rather than as an individual. Categories of thinking such as human personality or personal quality clearly show that every human being is exceptional and unique. For this reason, the human person cannot be expressed by means of concepts, because the properties or characteristics that one may

\footnotetext{
${ }^{6}$ According to Plato, at the moment of creation souls are practically the same. They do not acquire specific distinctive characteristics until they have united with bodies, but they do not attain a particular personality because they can unite with different bodies. Cf. Plato, Timaeus 41 D, 42 BC; Plato, Phaedo 249 B; Plato, The Republic 618 AB.

${ }^{7}$ Cf. ARISTOTLE, On the Soul 2.4.415 a 28-67.

${ }^{8}$ Zizioulas, Being as Communion, 28-30.

${ }^{9}$ Vladimir LossKy, "Redemption and Deification," in LOSSKY, In the Image and Likeness of God, trans. Thomas E. Bird (Crestwood, NY: St Vladimir's Seminary Press, 1985), 107.
} 
wish to use to refer to the person could be found in other individuals. ${ }^{10}$ Discourse on the concept of human person is impossible without reference to the complex philosophical tradition From the first centuries of Christianity, the Church Fathers and other Christian theologians made efforts to describe the reality of the human person in a comprehensible and timeless way. Did they succeed, or to what extent did they succeed, in accomplishing this? Vladimir Lossky claimed that he had not found developed teaching on the human person in patristic theology, but there was plenty of highly precise teaching on the Divine Persons there. At the same time, however, he was convinced that it was possible to find a Christian anthropology in the Fathers of the first eight centuries. ${ }^{11}$ The concept of person in the tradition of Eastern Christianity has its sources in reflection on the Divine Persons. The category of person is therefore marked, above all, by a reference to the reality of the Triune God. ${ }^{12}$ It was on this basis that the Church Fathers undertook work aimed at determining who man is as a person. This makes it impossible to understand the concept of human person without reference to the Divine Persons. In this sense, the Trinitarian dogma provides the basis for resolving anthropological problems. This is not easy, since the truth about God in three Divine Persons, constituting the peak of the Christian Revelation, is par excellence an antinomy for the human mind. ${ }^{13}$

Looking for an answer to the question of who the human person is in Christian theological thought, Vladimir Lossky is therefore right in regarding the focus on the personal mystery of the Holy Trinity as a necessary precondition. To the Greek Fathers of the Church, the point of departure for the broadly understood anthropological issues was the reality of God who is one but at the same time in three Persons. ${ }^{14}$ The God that Christians believe in is a personal God, not an impersonal monad. What was important in the Cappadocian fathers' theology was the emphasis on the role of the Person of

\footnotetext{
${ }^{10}$ LossKy, Teologia mistyczna Kościoła Wschodniego, 47.

${ }^{11}$ Vladimir Lossky, "The Theological Notion of the Human Person," in Lossky, In the Image and Likeness of God, 112: "For my part, I must admit that until now I have not found what one might call an elaborated doctrine of the human person in patristic theology alongside its very precise teaching on divine persons or hypostases. However there is a Christian anthropology among the Fathers of the first eight centuries."

${ }^{12}$ Cf. Vladimir Lossky, Teologia dogmatyczna, trans. Henryk Paprocki (Białystok: Bractwo Młodzieży Prawosławnej w Polsce, 2000), 22-25.

${ }^{13}$ LossKy, Teologia mistyczna Kościoła Wschodniego, 48.

${ }^{14}$ Zizioulas, Being as Communion, 36: "The concept of the person with its absolute and ontological content was born historically from the endeavor of the Church to give ontological expression to its faith in the Triune God."
} 
God the Father as the eternal cause of both the being and the existence of the remaining two Divine Persons. ${ }^{15}$ The fact that God exists because the Father exists suggests that His Being and His existence are the result of a free Person's existence. And only a person who loves in a free manner is a true being. ${ }^{16}$ In order to express the mystery of the personal God, the Church Fa-

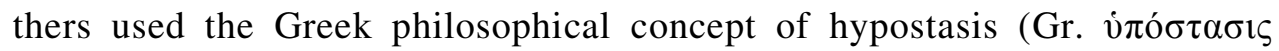
[hypostasis]). ${ }^{17}$ In this way, they wanted to express both absolute identity and absolute difference in ontological terms. A great terminological achievement was the introduction of the distinction in God between vitó $\sigma \alpha \sigma 1 \varsigma$ [hypostasis] and ovंoía [ousia], so as to express the irreducibility of

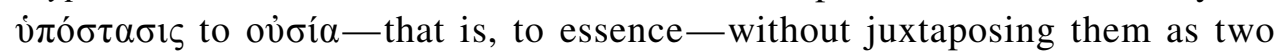

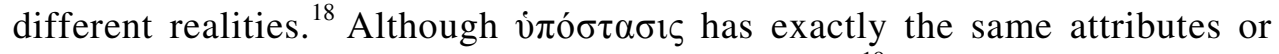

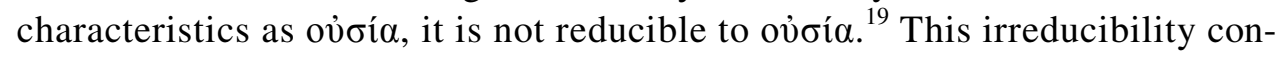
cerns only three Hypostases, which, in fact, are not three but a "Triunity." This is difficult to understand in logical terms, because "Just as the Three here is not an arithmetic number but indicates in the Triad of pure difference-a Triad which remains equal to the Monad-an infinite passage beyond the dyad of opposition, so the hypostasis as such, in as much as it is irreducible to the ousia, is no longer a conceptual expression but a sign which is introduced into the domain of the non-generalizable, pointing out the radically personal character of the God of Christian revelation." "20 Gregory of Nazianzus tries to explain the mystery of God's unity and trinity in his Oration on Holy Baptism: "No sooner do I conceive of the One than I am illumined by the Splendour of the Three; no sooner do I distinguish Them than I am carried back to the One. When I think of any One of the Three I think of Him as the Whole, and my eyes are filled, and the greater part of what I am thinking of escapes me. I cannot grasp the greatness of That One so as to attribute a greater greatness to the Rest. When I contemplate the Three together, I see

\footnotetext{
${ }^{15}$ Cf. Colin Gunton, "Persons and Particularity," in The Theology of John Zizioulas: Personhood and the Church, edited by Douglas H. Knight (Aldershot, England-Burlington, VT: Ashgate, 2007), 97.

${ }^{16}$ Cf. Zizioulas, Being as Communion, 18.

${ }^{17}$ Cf. Christos Yannaras, Postmodern Metaphysics, trans. Norman Russell (Brookline, MA: Holy Cross Orthodox Press, 2004), 171.

${ }^{18}$ Lossky, "The Theological Notion of the Human Person," 112. Cf. Aristotle PAPANIKOLAu, Being with God. Trinity, Apophaticism, and Divine-Human Communion (Notre Dame, IN: Notre Dame University Press, 2006), 53-65.

${ }^{19}$ Lossky, Teologia dogmatyczna, 25. Cf. GREGORY OF NYSSA, De differentia essentiae et hypostaseos [= Basilii Magni Epistula XXXVIII], 5. PG 32, 336C.

${ }^{20}$ Lossky, "The Theological Notion of the Human Person," 113.
} 
but one torch, and cannot divide or measure out the Undivided Light." 21 Vladimir Lossky emphasized the fact that, for St Gregory of Nazianzus, the aim of theological reflection was the contemplation of God and the praise of His glory. ${ }^{22}$ The human mind is unable to simultaneously apprehend the mystery of the Trinity of Divine Persons and the Unity of God. It struggles, trying to overcome the antinomy of unity and trinity, which forces it to engage in constant movement in order to rise above all intellectual concepts. As a result of the insoluble aporia, the mind achieves a higher and higher level of contemplative concentration through constant movement from unity to trinity and from trinity to unity. ${ }^{23}$ In the case of the Divine Persons, who are inseparably united, it is necessary to apply "spiritual arithmetic," as the sum of the three Divine Persons is always a unity. The number three with reference to God does not indicate quantity but refers to Divinity. The human mind would like to control the mystery of the Trinitarian God by reducing the Trinity to unity, or by making It an Essence manifesting itself in three ways (Sabellius' modalism), or by dividing this Essence into three different beings (Arius' tritheism). ${ }^{24}$

The Trinitarian irreducibility of the person to nature translates directly into anthropology. For this reason, Vladimir Lossky believed that, in anthropology it was necessary to overcome the limitation of the individualthat is, of a single being - stemming from person being intermingled with nature. While sharing a common nature, human persons are not its parts. Each human person is a whole that finds complete fulfilment in unity with God. The mystery of the Divine Being, in which there is a distinction between one nature and three Persons, is reflected in humanity, called to partake in the life of the Holy Trinity. Nature and person-the two poles of the human being - are called to fullness. Nature can find this fullness in unity, and person can find it in absolute diversity. It is wonderful that each human being unites with God in a way that is specific only to that particular person. The fullness of nature requires perfect communion of mankind-one body that materializes in the Church. ${ }^{25}$ The concept of "person" points to the

\footnotetext{
${ }^{21}$ Gregory of NaZianZuS, Oratio XL-In sanctum baptisma, 41. PG 36, 417 BC. English translation quoted from: New Advent (website), http://www.newadvent.org/fathers/310240.htm (accessed: 20.01.2018).

${ }^{22}$ Cf. Vladimir Lossky, The Vision of God, trans. Asheleigh Moorhouse (Crestwood, NY: St Vladimir's Seminary Press, 1983), 81.

${ }^{23}$ LOSSKY, Teologia mistyczna Kościoła Wschodniego, 41.

${ }^{24}$ Ibid., 42-43.

${ }^{25}$ Cf. ibid., 217.
} 
irreducibility of the human being to his or her nature. This does not mean "something" different from "another nature" but "someone" who is different from his or her own nature, someone who is above his or her own nature and at the same time within it, someone who exists as human nature by going beyond it, and someone who does not exist in himself or herself above this nature that he or she "personifies" and constantly transcends. ${ }^{26}$

Based on the difficulties stemming from the distinction between the human person or hypostasis and man treated as an individual or specific nature, Vladimir Lossky asks the following question: What should 'person' mean with reference to a particular human being? Is "person" some kind of highest quality of an individual, being an indicator of his or her perfection? And if so, is this determined by the fact of having been created in God's image and likeness,${ }^{27}$ or is it the principle of man's individuality? The author leaves these questions open, thus encouraging further research on Christian anthropology. ${ }^{28}$

\section{WESTERN CHRISTIAN UNDERSTANDING OF THE PERSON}

In Western Christianity, the still influential formula defining the person is the one proposed by Boethius. According to him, the person is "the individual substance of a rational nature" (Lat. naturae rationalis individua substantia) ${ }^{29}$ For centuries it was believed that what this definition highlighted in the mystery of the person was only individuality and rationality. Also in Vladimir Lossky's opinion, in the light of the Christological dogma, it is obvious that Boethius' definition is insufficient for establishing the concept of human person. ${ }^{30}$ It can only be understood as referring to "personi-

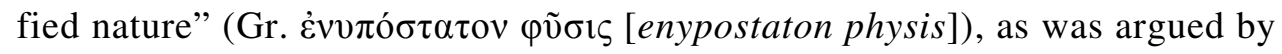

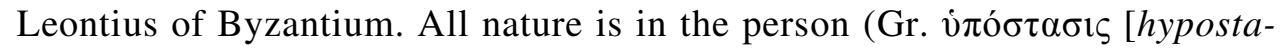

\footnotetext{
${ }^{26}$ Cf. LossKy, "The Theological Notion of the Human Person," 120.

${ }^{27}$ Cf. Nonna Verna Harrison, "The Human Person as Image and Likeness of God," in The Cambridge Companion to the Orthodox Christian Theology, ed. Mary B. Cunningham and Elizabeth Theokritoff (Cambridge: Cambridge University Press, 2008), 78-92.

${ }^{28}$ LOSSKY, "The Theological Notion of the Human Person," 119.

${ }^{29}$ BoEthius, "A Treatise Against Eutyches and Nestorius," in BoETHIUs, The Theological Tractates, trans. H.F. Stewart and E.K. Rand (London: W. Heinemann; New York: G.P. Putnam's Sons, 1918), 92. Christian Classics Ethereal Library (website), http://www.documentacatholicaomnia.eu/ 03d/0480-0524,_Boethius,_The_Theological_Tractates,_EN.pdf (accessed: 20.01.2018).

${ }^{30}$ Cf. Lossky, "The Theological Notion of the Human Person," 118.
} 
sis]); it is the person's nature and cannot exist in a different way. ${ }^{31}$ It was probably for the same reason that Richard of St Victor rejected Boethius' definition, delicately pointing out that substance answers the question quid, while person answer the question quis. Only the question quis can be answered with a proper noun that can refer to a person. ${ }^{32}$ Like many other Christian theologians, the author of The Mystical Theology of the Eastern Church took Boethius' concept of person out of the context in which it appears in A Treatise against Eutyches and Nestorius; the context concerned the relationship between the concepts of person and nature ${ }^{33}$ and showed that Boethius had doubts regarding how to define this concept the most accurately. ${ }^{34}$

St Thomas Aquinas reconstructed the concept of "individual substances," finding in them an abundance of creative energy which actualizes everything that exists. This new ontological category refers to all created beings, not only to human or angelic persons. According to Vladimir Lossky, the Thomistic distinction between essence and existence is insufficient for an ontological solution of the human person mystery. Based on the Palamite theology, it can be said that St. Thomas Aquinas, as a metaphysician, engaged in reflection at the level of energy rather than at the level of "the highest being" in Three Divine Persons or the "multipersonality" of the created cosmos. This led the author of The Mystical Theology of the Eastern Church to the conclusion that the level on which the problem of the human person is posed is beyond the scope of ordinarily understood ontology. And if it is a question of meta-ontology, then only God knows the answer. ${ }^{35}$

\footnotetext{
${ }^{31}$ LeOntius of ByZAntium, Contra Nestorianos et Eutychianos, 1. PG 86, 1277CD. Cf. LossKy, Teologia mistyczna Kościoła Wschodniego, 108.

${ }^{32}$ Cf. Richard of St Victor, De Trinitate IV, 7. PL 196, 934-935.

${ }^{33}$ Juliusz DomAŃSKI, “Trzy glossy do pojęć osoby i wspólnoty,” Acta Mediaevalia 22 (2009): 191: "Boecjuszowa definicja (Persona est naturae rationalis individua substantia) operuje [...] relacjonalnością wzajemną 'rozumnej natury' i 'jednostkowej substancji', sygnalizuje pewne dialektyczne między nimi napięcie. Napięcie między tym, co uniwersalne (natura rationalis), i tym, co jednostkowe (individua substantia)." [Boethius' definition (Persona est naturae rationalis individua substantia) uses [...] the mutual relationality of 'rational nature' and 'individual substance,' signaling a certain dialectical tension between them: a tension between what is universal (natura rationalis) and what is individual (individua substantia).]

${ }^{34}$ BoEthius, "A Treatise Against Eutyches and Nestorius," 81, 83. Christian Classics Ethereal Library (website), http://www.documentacatholicaomnia.eu/03d/0480-0524,_Boethius,_The_Theological _Tractates,_EN.pdf: "But the proper definition of Person is a matter of very great perplexity. For if every nature has person, the difference between nature and person is a hard knot to unravel; or if person is not taken as the equivalent of nature but is a term of less scope and range, it is difficult to say to what natures it may be extended, that is, to what natures the term person may be applied and what natures are dissociate from it." (accessed: 20.01.2018).

${ }^{35}$ Cf. Lossky, "The Theological Notion of the Human Person," 122-123.
} 
It is not easy to understand the distinction between nature and person, both with reference to God and with reference to humans. Still, all human persons share one human nature. This is an apophatic truth, because-as Vladimir Lossky argues - we have no access to the pure form of the human hypostasis. Our understanding of the person is usually closer to an individual or to that which is individual than to person in the strict sense of the term. This stems from person and individual being commonly equated with each other, as though they were one reality. Nowadays, person and individual are considered to be synonyms, referring to the same reality. ${ }^{36}$ From the ontological point of view, individual and person are not only different in meaning but in fact have opposite meanings, if we relate them to nature. An individual is a manifestation of a combination of person with elements belonging to the common nature, whereas a person refers to what is distinguished from nature. The problem becomes complicated, since in our earthly life we are able to get to know persons only through individuals, as individuals. But information about various individual characteristics, related to nature, is insufficient to establish who a given person is. As we collect information about others, we come to the conclusion that a certain mysterious, specific, and unique mystery of a particular person-which is the most precious in that person-is not accessible to out cognition. Character traits, related mainly to human nature, are repeatable, and a given human being as a person is someone who is one of a kind and incomparable with anyone else. A particular human being, who behaves according to his or her natural character traits, is "the least personal" because he or she appears to be an individual, the owner of his or her nature. As such, he or she remains in opposition to others, opposing their natures. One of the basic tenets of Christian anthropology is the belief that the concept of person encompasses freedom in relation to nature. Nature is not above the person. Nature cannot determine the person. This is of great significance for the understanding of the freedom of the human person, since the primacy of person over nature implies that the human person can be actualized only by renouncing his or her own will-namely, all that limits them and subjugates them to natural necessity. The outcome of self-affirmation, which consists in person being intermingled with nature, is the loss of true personal freedom. The precondition of selfactualization is the overcoming of one's individual limitedness in order to regain common nature. ${ }^{37}$

\footnotetext{
${ }^{36}$ LOSSKY, "Catholic Consciousness: Anthropological Implications of the Dogma of the Church," in LossKY, In the Image and Likeness of God, 185.

${ }^{37}$ LOSSKY, Teologia mistyczna Kościoła Wschodniego, 106-108.
} 
If human persons were the same as individuals, separate parts of the common nature, personal multiplicity would be intermingled with the individualistic and at the same time egoistic division of nature's unity. If we take into account the pure concept of person, which we relate to the Holy Trinity, we notice that, when using it, we are not treating the Divine Persons as three parts of one nature. By analogy, it can be said that the created person as a person means more than just an "individual being." The human person not so much is part of a whole as comprises a whole. Taking this perspective, Vladimir Lossky emphasizes that every human person should be treated as "a person of the common nature" - namely, a hypostasis of the entire created cosmos or, more precisely, of the earthly creation. ${ }^{38}$

Vladimir Lossky's theological reflection on the human being as a person inspired many researchers to engage in further analyses - not only theological but also philological, philosophical, social, and humanistic. The concept of "person" is extremely important for anthropological issues. It not only implies the appreciation of man's uniqueness and irreducibility to an individual rational being, but also constitutes an important contribution of Christianity to the civilization which has Christian roots. Vladimir Lossky has reminded us that the concept of "person" refers not only to man, but first of all to God, the Trinity of Holy Persons, in whose image and likeness man was created. Thus, the concept of "person" points to the original and ul-

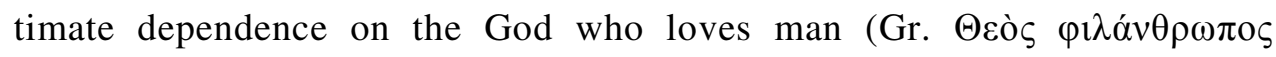
[Theos filanthrōpos]).

\section{BIBLIOGRAPHY}

Balthasar, Hans Urs von. "On the Concept of Person.” Communio 13 (1986): 18-26.

BoEthius, "A Treatise Against Eutyches and Nestorius." In BoEthius, The Theological Tractates, translated by H.F. Stewart and E.K. Rand, 73-127. London: W. Heinemann; New York: G.P. Putnam's Sons, 1918. Christian Classics Ethereal Library (website), http://www.documenta catholicaomnia.eu/03d/0480-0524,_Boethius,_The_Theological_Tractates,_EN.pdf (accessed: 20.01.2018).

Boethius. "Przeciw Eutychesowi i Nestoriuszowi" [A treatise against Eutyches and Nestorius]. Translated by Rafał Bielak and Agnieszka Kijewska. In BoETHIUs, Traktaty teologiczne [Theological treatises], 66-84. Kęty: Antyk, 2001.

Burgos, Juan Manuel. Personalizm. Autorzy i tematy nowej filozofii [Personalism. Authors and themes of the new philosophy]. Translated by Krzysztof Koprowski. Warsaw: Centrum Myśli Jana Pawła II, 2010.

\footnotetext{
${ }^{38}$ LossKy, "Catholic Consciousness,” 188.
} 
Clement, Olivier. Questions sur l'homme. Paris: Stock, 1972.

Crosby, John F. The Selfhood of the Human Person. Washington, D.C.: The Catholic University of America Press, 1996.

DomaŃSKI, Juliusz. "Trzy glossy do pojęć osoby i wspólnoty” [Three glosses on the concepts of person and community]. Acta Mediaevalia 22 (2009): 187-194.

Granat, Wincenty. Osoba ludzka. Próba definicji [The human person: An attempt at definition]. Sandomierz, Poland: Wydawnictwo Diecezjalne, 1961.

Gunton, Colin: "Persons and Particularity." In The Theology of John Zizioulas: Personhood and the Church, edited by Douglas H. Knight, 97-107. Aldershot, England-Burlington, VT: Ashgate, 2007.

HARRISOn, Nonna Verna. "The Human Person as Image and Likeness of God." In The Cambridge Companion to the Orthodox Christian Theology, edited by Mary B. Cunningham and Elizabeth Theokritoff, 78-92. Cambridge: Cambridge University Press, 2008.

KipPenberg, Hans G., Yme B. KuiPer, and Andy F. SAnders, eds. Concepts of Person in Religion and Thought. Berlin-New York, NY: De Gruyter, 1990.

Lossky, Vladimir. "Catholic Consciousness: Anthropological Implications of the Dogma of the Church." In Vladimir LossKY, In the Image and Likeness of God, translated by Thomas E. Bird, 183-194. Crestwood, NY: St Vladimir's Seminary Press, 1985.

LOSSKY, Vladimir. "Redemption and Deification." In Vladimir LOSSKY, In the Image and Likeness of God, translated by Thomas E. Bird, 97-110. Crestwood, NY: St Vladimir's Seminary Press, 1985.

Lossky, Vladimir. "The Theological Notion of the Human Person." In Vladimir Lossky, In the Image and Likeness of God, translated by Thomas E. Bird, 111-123. Crestwood, NY: St Vladimir's Seminary Press, 1985.

Lossky, Vladimir. Teologia dogmatyczna [Dogmatic theology]. Translated by Henryk Paprocki. Białystok: Bractwo Młodzieży Prawosławnej w Polsce, 2000.

Lossky, Vladimir. Teologia mistyczna Kościota Wschodniego [The Mystical Theology of the Eastern Church]. Translated by Maria Sczaniecka. Warsaw: PAX, 1989.

Lossky, Vladimir. The Vision of God. Translated by Asheleigh Morehouse. Crestwood, NY: St Vladimir's Seminary Press, 1985, 1983.

LuKes, Steven, Michael CARrithers, and Steven Collins, eds. The Category of Person: Anthropology, Philosophy, History. Cambridge: Cambridge University Press, 1987.

Papanikolau, Aristotle. Being with God. Trinity, Apophaticism, and Divine-Human Communion. Notre Dame, IN: University of Notre Dame Press, 2006.

Ratzinger, Joseph. "Concerning the Notion of Person in Theology." Communio 17 (1990): 439-454.

RoDZIŃSKI, Adam. Osoba i kultura [Person and culture]. Warsaw: Ośrodek Dokumentacji i Studiów Społecznych, 1985.

TOURNIER, Paul. Le personnage et la personne. Neuchâtel: Delachaux et Niestlé, 1954.

Vogel, Cornelia Johanna de. "The Concept of Personality in Greek and Christian Thought." In Studies in Philosophy and the History of Philosophy, edited by John K. Ryan, vol. 2, 20-60. Washington, D.C.: Catholic University of America Press, 1963. 
Yannaras, Christos. Postmodern Metaphysics. Translated by Norman Russell. Brookline, MA: Holy Cross Orthodox Press, 2004.

Zizıoulas, John D. Being as Communion. Studies in Personhood and the Church. London: Longman and Todd, 1985.

Translated by Piotr Czyżewski

The preparation of the English version of Roczniki Teologiczne (Annals of Theology) and its publication in electronic databases was financed under contract no. 836/P-DUN/2018 from the resources of the Minister of Science and Higher Education for the popularization of science. 